\title{
Pasteurella multocida non-native joint infection after a dog lick: A case report describing a complicated two-stage revision and a comprehensive review of the literature
}

\author{
Philip W Lam BScPhm MD ${ }^{1}$, Andrea V Page BScH MSc MD FRCPC ${ }^{1,2}$
}

PW Lam, AV Page. Pasteurella multocida non-native joint infection after a dog lick: A case report describing a complicated two-stage revision and a comprehensive review of the literature. Can J Infect Dis Med Microbiol 2015;26(4):212-217.

Prosthetic joint infections (PJIs) are commonly caused by pathogens such as Staphylococcus aureus and coagulase-negative staphylococci; however, other microbial etiologies and specific risk factors are increasingly recognized. Pasteurella multocida is a Gram-negative coccobacillus that is part of the normal oral flora in many animals, and is particularly common in dogs and cats. PJIs caused by $P$ multocida have been reported only rarely in the literature and typically occur in the context of an animal bite or scratch. The present article describes a $P$ multocida joint infection that occurred after a dog lick and complicated a two-stage revision arthroplasty. A comprehensive review of the literature regarding P multocida PJIs follows.

Key Words: Dog bite; Dog lick; Pasteurella multocida, Prosthetic joint infection

\begin{abstract}
Drosthetic joint infections (PJIs) are common, occurring in approximately $1 \%$ to $2 \%$ of all joint replacements (1). Bacterial seeding of the prosthetic joint can occur during surgery or afterward via hematogenous spread. Pathogens such as Staphylococcus aureus and coagulasenegative staphylococci account for the majority of PJIs; however, other factors, such as the joint involved, timing of infection postoperatively, and comorbidities, can influence the microbiology (1). Risk factors for PJIs include older age, diabetes, rheumatoid arthritis, immunosuppressive medications, malignancy and history of arthroplasty revision (1). Perioperative factors, such as hematoma formation, superficial surgical site infection, wound drainage and wound dehiscence, have also been identified as risk factors (1).

In the present report, we describe a two-stage revision arthroplasty that was complicated by a Pasteurella multocida joint infection following a dog lick, and present a comprehensive review of the literature surrounding P multocida PJIs.
\end{abstract}

\section{CASE PRESENTATION}

A 55-year-old woman presented to the emergency department with a five-day history of chills, progressive right hip pain and difficulty ambulating. Her medical history was significant for a right total hip arthroplasty eight years previously due to osteoarthritis and severe obesity. She experienced an acute postoperative wound infection requiring irrigation and debridement and a second infection two years later requiring a staged revision. One year before presentation, she began to experience a series of monomicrobial PJIs that were treated with a combination of surgery and antimicrobial therapy as follows: Staphylococcus lugdunensis (two-stage revision, ceftriaxone), Klebsiella

\section{L'infection à Pasteurella multocida non indigène d'une articulation léchée par un chien : rapport de cas d'une révision compliquée en deux étapes et analyse bibliographique approfondie}

Les infections sur prothèse articulaire (IPA) sont souvent causées par des pathogènes comme le Staphylococcus aureus et les staphylocoques à coagulase négative. Cependant, on constate de plus en plus d'autres étiologies microbiennes et de facteurs de risque particuliers. Le Pasteurella multocida, un coccobacille à Gram négatif qui fait partie de la flore orale normale de nombreux animaux, est particulièrement courant chez les chiens et les chats. Peu d'IPA causées par le P multocida sont signalées dans les publications scientifiques, mais elles se produisent surtout après une morsure ou une griffure d'animal. Le présent article décrit une infection à $P$ multocida qui s'est manifestée après que l'articulation a été léchée par un chien et une arthroplastie de révision compliquée en deux étapes. Une analyse bibliographique approfondie de l'IPA à $P$ multocida suit. pneumoniae (irrigation and debridement with liner exchange, ciprofloxacin), coagulase-negative Staphylococcus (first stage of a planned two-stage revision with cement spacer, vancomycin) and Candida albicans (cement spacer exchange, fluconazole). Two months before presentation, she underwent excision of all hardware in the hip as part of a planned two-stage joint revision given recurrent infections with the cement spacer in situ. At that time, she received a six-week course of ertapenem for a joint infection with class A extended-spectrum beta-lactamase (ESBL)-producing Escherichia coli, with a vacuum-assisted wound dressing of the surgical site.

At presentation, she was afebrile, but examination of the right hip revealed a nonhealing, erythematous wound with purulent discharge. She had leukocytosis $(13,320$ cells/ $\mu \mathrm{L})$ and elevated inflammatory markers (erythrocyte sedimentation rate $68 \mathrm{~mm} / \mathrm{s}$, C-reactive protein $132 \mathrm{mg} / \mathrm{L}$ ), and was immediately taken to the operating room for irrigation and debridement.

\begin{abstract}
Diagnosis
Three of three operative cultures of synovial tissue and fluid were positive for $P$ multocida (susceptible to ceftriaxone, imipenem, levofloxacin, meropenem, penicillin and trimethoprim/sulfamethoxazole) (Table 1) and Corynebacterium striatum (susceptible to vancomycin and gentamicin, resistant to erythromycin and penicillin) (Table 2). Bacterial identification was confirmed using fatty acid methyl ester analysis with gas chromatography, and susceptibilities were determined using Sensititre Susceptibility MIC Plates (TREK Diagnostic Systems, USA). Of note, she was also confirmed to be colonized with ESBL-producing organisms based on rectal swabs obtained as part of routine infection control screening practices then in place. On further
\end{abstract}

${ }^{1}$ Department of Medicine, University of Toronto; ${ }^{2}$ Division of Infectious Diseases, Mount Sinai Hospital, Toronto, Ontario

Correspondence: Dr Andrea V Page, Mount Sinai Hospital, Suite 427, 600 University Avenue, Toronto, Ontario M5G 1 X5.

Telephone 416-586-4800 Ext 7689, e-mail apage@mtsinai.on.ca 
TABLE 1

In vitro susceptibility profile of Pasteurella multocida isolate

\begin{tabular}{lcc}
\hline Antimicrobial agent & Susceptibility & MIC, $\boldsymbol{\mu g} / \mathbf{m L}$ \\
\hline Ceftriaxone & Susceptible & $\leq 0.03$ \\
Imipenem & Susceptible & $\leq 0.5$ \\
Levofloxacin & Susceptible & $\leq 0.03$ \\
Meropenem & Susceptible & $\leq 0.06$ \\
Penicillin & Susceptible & 0.12 \\
Trimethroprim/sulfamethoxazole & Susceptible & $\leq 0.06$ \\
\hline MIC Minimum inhibitory concentration & &
\end{tabular}

questioning, she was found to live with five dogs and two cats, and reported allowing her dogs to lick a superficial laceration on her right lower leg that she had sustained in a fall just before symptom onset; she denied allowing her pets to lick her surgical wound site. On the basis of her most recent culture results and known ESBL colonization, she was treated with intravenous vancomycin and ertapenem for six weeks. One month following admission, she was discharged to a rehabilitation facility with instructions to avoid close pet contact with any unhealed or open wounds. She responded well to antimicrobial therapy and a vacuum-assisted dressing. Two months later, the patient underwent the second stage of her planned two-stage revision, with hip prosthesis re-implantation without complications. She remains free of infection after 10 months of follow-up.

\section{DISCUSSION}

P multocida is a Gram-negative coccobacillus that is part of the normal oral flora in many animals, including domestic dogs and cats $(2,3)$. Infections caused by P multocida may follow an animal bite or scratch, and range from cellulitis to septic arthritis and osteomyelitis (4). Respiratory infections can also occur, especially in patients with a history of pulmonary disease or immune suppression (4). Other less common infections include bacteremia, endocarditis, meningitis and intra-abdominal infections (4).

Although our case is unique in that infection occurred after excision arthroplasty in the midst of a two-stage revision, PJIs caused by $P$ multocida have been reported in the literature and typically occur in the context of an animal bite or scratch. A comprehensive literature review revealed 32 documented cases of $P$ multocida PJIs, all of which involved either the hip or knee joint (Table 3) (5-35).

Of the 32 documented cases, almost all patients had a history of animal contact, with 26 cases of soft tissue injury as a result. Twenty-two of the cases involved cats, while 10 cases involved dogs. Women have been shown to experience cat bites more frequently compared with men (36), and this may explain why 26 of the 32 reported cases of P multocida PJIs involved women. Known risk factors for PJIs that were also present in patients with P multocida PJIs included older age (mean 66.7 years), rheumatoid arthritis (11 of 32 patients [34.4\%]), corticosteroid use (10 of 32 patients [31.3\%]), other immunosuppressive therapy (two of 32 patients [6.3\%]) and malignancy (one of 32 patients [3.1\%]).

The presumed pathogenesis of $P$ multocida PJIs following animal contact involves the inoculation of bacteria into soft tissues causing bacteremia and subsequent hematogenous seeding of prosthetic material. This is supported by the fact that most documented cases of P multocida PJI occur remote from prosthesis implantation (months to years) and shortly after animal contact (days to weeks) (Table 3). Only two cases documented animal contact $>1$ month before onset of clinical signs or symptoms $(16,31)$.

Despite the importance of biofilm formation in the pathogenesis of typical PJIs, the characteristics of $P$ multocida biofilm formation have not been well studied. Animal strains of $P$ multocida have been shown to produce biofilms in vitro (37); however, in vivo evidence is lacking. Romanò et al (31) performed an in vitro spectrophotometric screening with positive control testing in their reported case of $P$ multocida PJI but found no biofilm production in their isolate.
TABLE 2

In vitro susceptibility profile of Corynebacterium striatum isolate

\begin{tabular}{lcc}
\hline Antimicrobial agent & Susceptibility & $\mathbf{M I C}, \boldsymbol{\mu g} / \mathbf{m L}$ \\
\hline Erythromycin & Resistant & $\geq 4$ \\
Gentamicin & Susceptible & $\leq 2$ \\
Penicillin & Resistant & 8 \\
Vancomycin & Susceptible & 0.5 \\
\hline
\end{tabular}

MIC Minimum inhibitory concentration

The case we presented represents only the sixth documented report of $P$ multocida non-native joint infection following a dog lick, and the first to occur after excision arthroplasty. Our patient's extensive history of PJIs requiring multiple surgical revisions likely contributed to the increased risk for subsequent infections. Although the patient's hardware was surgically removed two months before presentation, underlying joint damage likely facilitated bacterial adhesion and infection. We suspect the patient's superficial laceration on the lower leg served as a portal of entry for bacteria from the dog's saliva, facilitating hematogenous spread and seeding of the damaged hip joint. Although direct inoculation of the surgical wound by a dog lick was possible, both the history and the presence of a vacuum dressing made this less likely.

$P$ multocida infections following close pet contact have also occurred with other foreign materials including breast prostheses $(38,39)$, vascular stent graft $(40)$, peritoneal dialysis catheters $(41)$ and hemodialysis lines (42). However, foreign material is not a prerequisite for infection, as illustrated by the present case (postexcision arthroplasty), as well as in three cases of respiratory pasteurellosis, which developed in patients providing palliative care to their pets (43). These cases demonstrate the importance of counselling patients about the risk for zoonotic infection and the steps that can be taken to potentially reduce this risk, including good hand hygiene after pet contact and before dressing changes, covering the wound at all times, avoiding direct pet contact with the surgical site or other wounds, and reporting any animal-induced wounds to a physician. Moreover, facilities that use animal-assisted interventions (also known as pet therapy) should ensure that institution-specific infection control policies are consistent with published guidelines (44) to minimize the risk for zoonotic infection.

Isolates of $P$ multocida from human infections continue to be susceptible to most antibiotics including penicillin, amoxicillin-clavulanate, doxycycline, third-generation cephalosporins, fluoroquinolones and carbapenems (45-47). Infections caused by beta-lactamase producing $P$ multocida have been reported in respiratory infections but remain uncommon $(48,49)$. It is important to note that while most human isolates remain susceptible to beta-lactams, strains isolated from animals have demonstrated marked resistance to a variety of antibiotics (50). Furthermore, empirical treatment of a PJI in the context of a recent animal bite should be directed against a polymicrobial microbiota including Gram-positive and Gram-negative aerobes, and anaerobes, consistent with the expected oral flora of the animal.

Early cases of $P$ multocida PJIs were treated with penicillin alone $(6-9,11)$. Although there were more cases of treatment failure in this group, these patients were also less likely to be treated surgically (Table 3). More recent reports have successfully used a third-generation cephalosporin, beta-lactam/beta-lactamase inhibitor combination or fluoroquinolone in addition to surgical intervention. Interestingly, linezolid, an oxazolidinone with Gram-positive activity has been shown to demonstrate in vitro activity against $P$ multocida (51). Ferguson et al (33) successfully treated a penicillin-allergic patient with $P$ multocida PJI using a combination of linezolid and ciprofloxacin in conjunction with surgical debridement, joint lavage and replacement of the joint liner. It is unclear whether combination therapy is more effective than monotherapy for the treatment of $P$ multocida PJIs, despite several case reports describing the successful use of dual antibiotics $(13,20,22,25,26,30,31,33,35)$. Current guidelines recommend treating 
TABLE 3

Literature review of documented Pasteurella multocida prosthetic joint infections

\begin{tabular}{|c|c|c|c|c|c|c|c|c|c|}
\hline Author (reference), year & $\begin{array}{l}\text { Age, } \\
\text { years/ } \\
\text { sex }\end{array}$ & $\begin{array}{c}\text { Risk } \\
\text { factors }\end{array}$ & Site & $\begin{array}{l}\text { Time from } \\
\text { prosthesis }\end{array}$ & $\begin{array}{l}\text { Animal } \\
\text { contact }\end{array}$ & $\begin{array}{c}\text { Time to } \\
\text { symptoms }\end{array}$ & Surgical intervention & Antibiotic treatment ${ }^{\star}$ & Outcome \\
\hline Griffin et al (5), 1975 & $64 / F$ & RA, CS & TKA & 6 months & Cat scratch & 2 days & None & Ampicillin & Cure \\
\hline Maurer et al (6), 1975 & $55 / F$ & RA, CS & TKA & Years & Dog lick & - & None & Penicillin $\times 2$ weeks & Cure \\
\hline Sugarman et al (7), 1975 & $33 / F$ & RA, CS & TKA & 5 weeks & Dog lick & - & None & Penicillin $\times 60$ weeks & $\begin{array}{l}\text { Failure, } \\
\text { revision }\end{array}$ \\
\hline $\begin{array}{l}\text { Arvan and Goldberg (8), } \\
1978\end{array}$ & $72 / F$ & NR & TKA & 4 months & Cat bite & 1 week & $\begin{array}{l}\text { Debridement, joint lavage } \\
\text { and irrigation/suction } \\
\text { drainage ( } 2 \text { weeks) }\end{array}$ & Penicillin $\times 55$ weeks & Cure \\
\hline Spagnuolo (9), 1978 & $72 / F$ & NR & TKA & 4 months & Cat bite & 5 days & None & Penicillin $\times 6$ weeks & Cure \\
\hline $\begin{array}{l}\text { Gomez-Reino et al (10), } \\
1980\end{array}$ & $64 / F$ & NR & TKA & 3 years & Cat bite & 1 day & None & $\begin{array}{l}\text { Cephalothin } \\
\times 6 \text { weeks, cephalexin } \\
\times 2 \text { weeks }\end{array}$ & $\begin{array}{l}\text { Failure, } \\
\text { revision }\end{array}$ \\
\hline $\begin{array}{l}\text { Mellors and Schoen (11), } \\
1984\end{array}$ & $68 / F$ & $\mathrm{RA}, \mathrm{CS}$ & $\begin{array}{c}\mathrm{B} / \mathrm{L} \\
\mathrm{TKA}\end{array}$ & NR & Cat scratch & 4 days & Joint lavage & Penicillin $\times 6$ weeks & Cure \\
\hline $\begin{array}{l}\text { Orton and Fulcher (12), } \\
1984\end{array}$ & $74 / F$ & NR & $\begin{array}{c}\text { B/L } \\
\text { TKA }\end{array}$ & 3 years & Cat bite & $12 \mathrm{~h}$ & None & $\begin{array}{l}\text { Ampicillin } \times 17 \text { days, } \\
\text { penicillin } \\
+ \text { tetracycline } \\
\times 12 \text { weeks }\end{array}$ & $\begin{array}{l}\text { Failure, } \\
\text { revision }\end{array}$ \\
\hline $\begin{array}{l}\text { Braithwaite and Giddins (13), } \\
1992\end{array}$ & $48 / F$ & Diabetes & THA & 14 years & Cat bite & NR & Single stage revision & $\begin{array}{l}\text { Penicillin + flucloxacillin } \\
\times 6 \text { weeks }\end{array}$ & Cure \\
\hline $\begin{array}{l}\text { Gabuzda and Barnett (14), } \\
1992\end{array}$ & $88 / F$ & NR & TKA & 10 months & Cat bite & Days & $\begin{array}{l}\text { Debridement, removal } \\
\text { of prosthesis, placement } \\
\text { of cement spacer }\end{array}$ & $\begin{array}{l}\text { Ampicillin/sulbactam } \\
\text { ×3 weeks, } \\
\text { penicillin } \\
\times 3 \text { weeks }\end{array}$ & Cure \\
\hline $\begin{array}{l}\text { Guion and Sculco (15), } \\
1992\end{array}$ & $45 / F$ & $\mathrm{RA}, \mathrm{CS}$ & TKA & 2 years & Dog scratch & Days & Two-stage revision & $\begin{array}{r}\text { Cefotaxime } \\
\times 6 \text { weeks }\end{array}$ & Cure \\
\hline Antuna et al (16), 1997 & $73 / \mathrm{F}$ & RA & TKA & 1 year & Dog bite & 2 months & Single-stage revision & $\begin{array}{l}\text { Ciprofloxacin } \\
\times 10 \text { weeks }\end{array}$ & Cure \\
\hline $\begin{array}{l}\text { Maradona et al (17), } \\
1997\end{array}$ & $73 / F$ & Diabetes & TKA & 6 months & Dog bite & 45 days & $\begin{array}{c}\text { Debridement, } \\
\text { joint lavage }\end{array}$ & $\begin{array}{l}\text { Penicillin } \times 3 \text { weeks, } \\
\text { ciprofloxacin } \\
\times 3 \text { weeks }\end{array}$ & Cure \\
\hline Takwale et al (18), 1997 & $57 / F$ & $\begin{array}{l}\mathrm{RA}, \mathrm{MTX} \\
\mathrm{CS}\end{array}$ & THA & 12 years & Cat scratch & 1 day & Two-stage revision & $\begin{array}{l}\text { Benzyl penicillin } \\
\times 4 \text { weeks, ciprofloxacin } \\
\times 8 \text { weeks }\end{array}$ & Cure \\
\hline Chikwe et al (19), 2000 & $69 / \mathrm{M}$ & NR & THA & 4 years & Dog contact & - & Two-stage revision & Unknown & Cure \\
\hline $\begin{array}{l}\text { Ciampolini et al (20), } \\
2004\end{array}$ & $73 / F$ & NR & TKA & 14 months & Cat scratch & 2 weeks & Two-stage revision & $\begin{array}{l}\text { Benzyl penicillin } \\
+ \text { ciprofloxacin, } \\
\text { amoxicillin + ciprofloxacin } \\
\times 6 \text { weeks }\end{array}$ & Cure \\
\hline $\begin{array}{l}\text { Mehta and Mackie (21), } \\
2004\end{array}$ & $84 / F$ & $\mathrm{RA}, \mathrm{CS}$ & THA & 15 years & Cat scratch & 1 month & Single-stage revision & $\begin{array}{l}\text { Benzyl penicillin } \\
\times 1 \text { week, ciprofloxacin } \\
\times 7 \text { weeks }\end{array}$ & Cure \\
\hline $\begin{array}{l}\text { Mehta and Mackie (21), } \\
2004\end{array}$ & $57 / F$ & $\begin{array}{l}\mathrm{RA}, \mathrm{MTX} \\
\mathrm{CS}\end{array}$ & THA & 10 years & Cat scratch & NR & Two-stage revision & $\begin{array}{l}\text { Benzyl penicillin } \\
\text { ×4 weeks, ciprofloxacin } \\
\times 8 \text { weeks }\end{array}$ & Cure \\
\hline Polzhofer et al (22), 2004 & $73 / F$ & NR & TKA & 6 months & Cat bite & Days & $\begin{array}{l}\text { Arthroscopic debride- } \\
\text { ment, synovectomy, } \\
\text { irrigation/suction drain- } \\
\text { age ( } 6 \text { days) }\end{array}$ & $\begin{array}{l}\text { Ampicillin/sulbactam + } \\
\text { clindamycin } \\
\times 3 \text { weeks }\end{array}$ & Cure \\
\hline Stiehl et al (23), 2004 & $63 / \mathrm{M}$ & NR & TKA & 12 days & $\begin{array}{l}\text { Dog contact, } \\
\text { horse injury }\end{array}$ & - & Two-stage revision & $\begin{array}{l}\text { Ciprofloxacin and } \\
\text { piperacillin/tazobactam }\end{array}$ & Cure \\
\hline Zebeede et al (24) 2004 & $41 / \mathrm{F}$ & $\begin{array}{l}\text { SLE, APS, } \\
\text { CS }\end{array}$ & TKA & 2 years & Cat scratch & 2 weeks & None & $\begin{array}{l}\text { Ciprofloxacin } \\
\times 12 \text { weeks }\end{array}$ & Cure \\
\hline Heym et al (25), 2006 & $72 / F$ & NR & TKA & 1 year & Dog lick & 3 weeks & $\begin{array}{l}\text { Synovectomy, removal } \\
\text { with reimplantation }\end{array}$ & $\begin{array}{l}\text { Doxycycline }+ \text { amoxicillin } \\
\times 8 \text { weeks }\end{array}$ & $\begin{array}{l}\text { Failure, } \\
\text { revision }\end{array}$ \\
\hline Serrano et al (26), 2007 & 79/M & NR & TKA & 6 years & Cat scratch & NR & Joint lavage & $\begin{array}{l}\text { Amoxicillin/clavulanate } \\
\times 3 \text { weeks, ciprofloxacin } \\
\times 4 \text { weeks }+ \text { TMP/SMX } \\
\times 12 \text { weeks }\end{array}$ & Cure \\
\hline $\begin{array}{l}\text { Kadakia and Langkamer (27), } \\
2008\end{array}$ & $80 / F$ & $\begin{array}{c}\text { Breast } \\
\text { carcinoma }\end{array}$ & TKA & 9 months & Cat bite & $\begin{array}{l}8-10 \\
\text { days }\end{array}$ & Arthroscopic joint lavage & $\begin{array}{l}\text { Cefuroxime } \\
\times 2 \text { weeks, ciprofloxacin } \\
\times 8 \text { weeks }\end{array}$ & Cure \\
\hline
\end{tabular}


TABLE 3 - CONTINUED

Literature review of documented Pasteurella multocida prosthetic joint infections

\begin{tabular}{|c|c|c|c|c|c|c|c|c|c|}
\hline Author (reference), year & $\begin{array}{l}\text { Age, } \\
\text { years/ } \\
\text { sex }\end{array}$ & $\begin{array}{c}\text { Risk } \\
\text { factors }\end{array}$ & Site & $\begin{array}{l}\text { Time from } \\
\text { prosthesis }\end{array}$ & $\begin{array}{l}\text { Animal } \\
\text { contact }\end{array}$ & $\begin{array}{c}\text { Time to } \\
\text { symptoms }\end{array}$ & Surgical intervention & Antibiotic treatment* & Outcome \\
\hline Miranda et al (30), 2013 & $64 / \mathrm{M}$ & NR & TKA & 1 year & $\begin{array}{l}\text { Cat scratch/ } \\
\text { bite }\end{array}$ & 9 days & $\begin{array}{l}\text { Joint lavage, } \\
\text { debridement, } \\
\text { replacement of spacer }\end{array}$ & $\begin{array}{l}\text { Amoxicillin/clavulanate }+ \\
\text { levofloxacin } \\
\times 6 \text { weeks }\end{array}$ & Cure \\
\hline Romanò et al (31), 2013 & $82 / F$ & RA & TKA & 10 years & Cat scratch & 5 months & $\begin{array}{l}\text { Debridement and } \\
\text { replacement of } \\
\text { tibial tray }\end{array}$ & $\begin{array}{l}\text { Amoxicillin/clavulanate } \\
\times 34 \text { days }+ \text { ciprofloxacin } \\
\times 6 \text { weeks }\end{array}$ & Cure \\
\hline $\begin{array}{l}\text { Subramanian et al (32), } \\
2013\end{array}$ & $47 / M$ & NR & TKA & 23 days & $\begin{array}{r}\text { Probable } \\
\text { dog lick }\end{array}$ & - & $\begin{array}{l}\text { Debridement, joint } \\
\text { lavage and } \\
\text { replacement of liner }\end{array}$ & $\begin{array}{l}\text { Cefuroxime } \times 2 \text { weeks, } \\
\text { doxycycline } \times 6 \text { weeks }\end{array}$ & Cure \\
\hline Ferguson et al (33), 2014 & $67 / F$ & NR & TKA & 13 weeks & Dog lick & - & $\begin{array}{l}\text { Debridement, joint } \\
\text { lavage and } \\
\text { replacement of insert }\end{array}$ & $\begin{array}{l}\text { Linezolid } \times 4 \text { weeks } \\
+ \text { ciprofloxacin } \\
\times 8 \text { weeks }\end{array}$ & Cure \\
\hline Vélez et al (34), 2014 & $75 / \mathrm{M}$ & NR & TKA & 16 months & Cat bite & 2 days & $\begin{array}{l}\text { Debridement, and } \\
\text { replacement of spacer }\end{array}$ & $\begin{array}{l}\text { Ampicillin/sulbactam } \\
\times 4 \text { weeks, } \\
\text { amoxicillin/clavulanate } \\
\times 24 \text { weeks }\end{array}$ & Cure \\
\hline $\begin{array}{l}\text { Alsaffar and Gaur (35), } \\
2014\end{array}$ & $74 / F$ & NR & THA & 26 years & Cat bite & 4 days & Joint lavage & $\begin{array}{l}\text { Amoxicillin + ciprofloxacin } \\
\times 8 \text { weeks }\end{array}$ & Cure \\
\hline
\end{tabular}

*Antibiotics separated by commas denote subsequent change in antibiotics, antibiotics separated by plus sign denote concurrent use. APS Antiphospholipid antibody syndrome; B/L Bilateral; CS Corticosteroids; F Female; M Male; MTX Methotrexate; NR Not reported; RA Rheumatoid arthritis; SLE Systemic lupus erythematosus; THA Total hip arthroplasty; TKA Total knee arthroplasty

nonstaphylococcal PJIs with four to six weeks of antimicrobial therapy (52). Of the 29 case reports with documented duration of therapy, 27 were treated with at least four weeks of antibiotics and 16 were treated with $>6$ weeks of antibiotics (Table 3 ).

The present report represents the first case of $P$ multocida joint infection successfully treated with ertapenem. The decision to treat with ertapenem was based on its documented efficacy in vitro against $P$ multocida (45), the patient's positive ESBL screening swabs and history of PJI caused by ESBL-producing organisms and the ease of outpatient dosing. The presence of $\mathrm{C}$ striatum in all operative cultures also prompted treatment with vancomycin. In one study of the microbiology of infections after animal-induced injuries, Corynebacterium species accounted for $12 \%$ of aerobic bacteria isolated from infected dog bite wounds (53). However, Corynebacterium species are part of normal human skin flora and, therefore, may have entered the wound from the patient's skin postoperatively during prolonged wound healing.

The optimal surgical management of PJIs should be individualized. Our literature review demonstrated a wide spectrum of surgical interventions, including no intervention (seven of 32 patients [21.9\%]), lavage only (four of 32 patients [12.5\%]), debridement and lavage (four of 32 patients [12.5\%]), debridement with replacement of exchangeable components (six of 32 patients [18.8\%]), single-stage revision (four of 32 patients [12.5\%]) and two-stage revision (six of 32 patients [18.8\%]). Earlier case reports of $P$ multocida PJIs were more likely to be treated nonoperatively. Of the seven patients treated nonoperatively, three $(42.9 \%)$ failed antimicrobial therapy alone $(7,10,12)$. The benefits of less-invasive interventions must be balanced with the risk of treatment failure. Algorithms have been developed by expert panels to identify patients with PJIs suitable for less-invasive interventions $(52,54)$. Factors in the algorithm include duration of illness, extent of soft tissue infection, presence of coexisting illness, surgical risk, stability of implant and bacterial susceptibility to antibiotics $(52,54)$. However, these algorithms do not specifically address PJIs associated with zoonotic pathogens. Our patient underwent irrigation and debridement because there was no prosthetic material present at the time of infection.

Several authors of previous case reports have advocated for the use of prophylactic antibiotics in all individuals with a prosthetic joint who have sustained an animal bite, especially if other risk factors are present (such as rheumatoid arthritis or corticosteroid use). Proposed antibiotics include penicillin (9), oxacillin (12), amoxicillin (18), cefuroxime (18) and amoxicillin/clavulanate (20). Recent guidelines have recommended antibiotic prophylaxis in all individuals with bite wounds at high risk for developing infection, such as those with significant immunocompromise (diabetes, steroid use, HIV, peripheral vascular disease), advanced liver disease, edema of the affected area and wounds involving deeper structures (55). To our knowledge, the use of prophylactic antibiotics following an animal bite or scratch in individuals with a prosthetic joint has not been directly addressed.

\section{CONCLUSION}

The present report represents the sixth documented case of $P$ multocida non-native joint infection following a dog lick, and the first to occur in the midst of a two-stage revision. The accompanying literature review of PJIs caused by $\mathrm{P}$ multocida is the most comprehensive performed to date and includes all 32 cases reported in the literature. While PJIs due to P multocida classically occur following an animal bite or scratch, our review highlights the fact that penetrating trauma is not a prerequisite for infection. It is important for clinicians to ask about animal exposure when evaluating a patient with a PJI, particularly if the infection has occurred remote from the surgery, so that the appropriate empirical therapy can be chosen. Our literature review also documented other risk factors that may increase the risk for $P$ multocida PJI following an animal-induced wound, including rheumatoid arthritis, corticosteroids, other immunosuppressive therapy and malignancy. In light of the case presented here, it is reasonable to counsel patients about the risk for zoonotic infections of surgical wounds and the steps that can be taken to potentially reduce this risk, such as maintaining good hand hygiene after pet contact, keeping wounds covered, avoiding direct pet contact with any unhealed, uncovered or open wounds, and reporting all significant animal-induced wounds to a physician.

DISCLOSURES: The authors have no financial disclosures or conflicts of interest to declare. 


\section{REFERENCES}

1. Tande AJ, Patel R. Prosthetic joint infection. Clin Microbiol Rev 2014;27:302-345.

2. Elliott DR, Wilson M, Buckley CMF, Spratt DA. Cultivable oral microbiota of domestic dogs. J Clin Microbiol 2005;43:5470-76.

3. Freshwater A. Why your housecat's trite little bite could cause you quite a fright: A study of domestic felines on the occurrence and antibiotic susceptibility of Pasteurella multocida. Zoonoses Public Health 2008;55:507-13.

4. Weber DJ, Wolfson JS, Swartz MN, Hooper DC. Pasteurella multocida infections. Report of 34 cases and review of the literature. Medicine (Baltimore) 1984;63:133-154.

5. Griffin AJ, Barber HM. Letter: Joint infection by Pasteurella multocida. Lancet 1975;1:1347-48.

6. Maurer KH, Hasselbacher P, Schumacher HR. Letter: Joint infection by Pasteurella multocida. Lancet 1975;2:409.

7. Sugarman M, Quismorio FP, Patzakis MJ. Letter: Joint infection by Pasteurella multocida. Lancet 1975;2:1267.

8. Arvan GD, Goldberg V. A case report of total knee arthroplasty infected by Pasteurella multocida. Clin Orthop Relat Res 1978;132:167-9.

9. Spagnuolo PJ. Pasteurella multocida infectious arthritis. Am J Med Sci 1978;275:359-63.

10. Gomez-Reino JJ, Shah M, Gorevic P, Lusskin R. Pasteurella multocida arthritis. Case report. J Bone Joint Surg Am 1980;62:1212-13.

11. Mellors JW, Schoen RT. Pasteurella multocida prosthetic joint infection. Ann Emerg Med 1985;14:617.

12. Orton DW, Fulcher WH. Pasteurella multocida: Bilateral septic knee joint prostheses from a distant cat bite. Ann Emerg Med 1984;13:1065-67.

13. Braithwaite BD, Giddins G. Pasteurella multocida infection of a total hip arthroplasty. A case report. J Arthroplasty 1992;7:309-10.

14. Gabuzda GM, Barnett PR. Pasteurella infection in a total knee arthroplasty. Orthop Rev 1992;21:601, 604-5.

15. Guion TL, Sculco TP. Pasteurella multocida infection in total knee arthroplasty. Case report and literature review. J Arthroplasty 1992;7:157-60.

16. Antuna SA, Mendez JG, Castellanos JL, Jimenez JP. Late infection after total knee arthroplasty caused by Pasteurella multocida. Acta Orthop Belg 1997;63:310-12.

17. Maradona JA, Asensi V, Carton JA, Rodriguez Guardado A, Lizon Castellano J. Prosthetic joint infection by Pasteurella multocida. Eur J Clin Microbiol Infect Dis 1997;16:623-25.

18. Takwale VJ, Wright ED, Bates J, Edge AJ. Pasteurella multocida infection of a total hip arthroplasty following cat scratch. J Infect 1997;34:263-64.

19. Chikwe J, Bowditch M, Villar RN, Bedford AF. Sleeping with the enemy: Pasteurella multocida infection of a hip replacement. J R Soc Med 2000;93:478-9.

20. Ciampolini J, Timperley J, Morgan M. Prosthetic joint infection by cat scratch. J R Soc Med 2004;97:441-2.

21. Mehta H, Mackie I. Prosthetic joint infection with Pasturella multocida following cat scratch: A report of 2 cases. J Arthroplasty 2004;19:525-527.

22. Polzhofer GK, Hassenpflug J, Petersen W. Arthroscopic treatment of septic arthritis in a patient with posterior stabilized total knee arthroplasty. Arthroscopy 2004;20:311-13.

23. Stiehl JB, Sterkin LA, Brummitt CF. Acute Pasteurella multocida in total knee arthroplasty. J Arthroplasty 2004;19:244-47.

24. Zebeede E, Levinger U, Weinberger A. Pasteurella multocida infectious arthritis. Isr Med Assoc J 2004;6:778-9.

25. Heym B, Jouve F, Lemoal M, Veil-Picard A, Lortat-Jacob A, Nicolas-Chanoine MH. Pasteurella multocida infection of a total knee arthroplasty after a "dog lick". Knee Surg Sports Traumatol Arthrosc 2006;14:993-7.

26. Serrano MT, Menéndez JN, García Bde L, Fernández ML. Infección de prótesis articular de rodilla por Pasteurella multocida. Enferm Infecc Microbiol Clin 2007;25:492.

27. Kadakia AP, Langkamer VG. Sepsis of total knee arthroplasty after domestic cat bite: Should we warn patients? Am J Orthop 2008;37:370-371

28. Blanco JF, Pescador D, Martin JM, Cano C, Sanchez MD. Acute infection of total knee arthroplasty due to a cat scratch in a patient with rheumatoid arthritis. J Clin Rheumatol 2012;18:314-15.
29. Heydemann J, Heydemann JS, Antony S. Acute infection of a total knee arthroplasty caused by Pasteurella multocida: A case report and a comprehensive review of the literature in the last 10 years. Int J Infect Dis 2010;14(Suppl 3):e242-5.

30. Miranda I, Angulo M, Amaya JV. Acute total knee replacement infection after a cat bite and scratch: A clinical case and review of the literature. Rev Esp Cir Ortop Traumatol 2013;57:300-5.

31. Romanò CL, De Vecchi E, Vassena C, Manzi G, Drago L. A case of a late and atypical knee prosthetic infection by no-biofilm producer Pasteurella multocida strain identified by pyrosequencing. Pol J Microbiol 2013;62:435-8.

32. Subramanian B, Holloway E, Townsend R, Sutton P. Infected total knee arthroplasty due to postoperative wound contamination with Pasteurella multocida. BMJ Case Rep 2013;2013:10.1136/bcr-2013. 009973.

33. Ferguson KB, Bharadwaj R, MacDonald A, Syme B, Bal AM. Pasteurella multocida infected total knee arthroplasty: A case report and review of the literature. Ann R Coll Surg Engl 2014;96:e1-4.

34. Velez FA, Laboy Ortiz IE, Lopez R, Sanchez A, Colon M, Hernan Martinez J. Pasteurella multocida: A nightmare for a replaced joint and the challenge to save it. Bol Asoc Med PR 2014;106:43-5.

35. Alsaffar L, Gaur S. Acute infection of a total hip arthroplasty by Pasteurella multocida successfully treated with antibiotics and joint washout. J Med Cases 2014;5:411-12.

36. MacBean CE, Taylor DM, Ashby K. Animal and human bite injuries in Victoria, 1998-2004. Med J Aust 2007;186:38-40.

37. Olson ME, Ceri H, Morck DW, Buret AG, Read RR. Biofilm bacteria: Formation and comparative susceptibility to antibiotics. Can J Vet Res 2002;66:86-92.

38. Johnson LB, Busuito MJ, Khatib R. Breast implant infection in a cat owner due to Pasteurella multocida. J Infect 2000;41:110-11.

39. Mathieu D, Rodriguez H, Jacobs F. Breast prosthesis infected by Pasteurella multocida. Acta Clin Belg 2008;63:351.

40. Silberfein EJ, Lin PH, Bush RL, Zhou W, Lumsden AB. Aortic endograft infection due to Pasteurella multocida following a rabbit bite. J Vasc Surg 2006;43:393-5.

41. Sol PM, van de Kar NC, Schreuder MF. Cat induced Pasteurella multocida peritonitis in peritoneal dialysis: A case report and review of the literature. Int J Hyg Environ Health 2013;216:211-13.

42. Boinett C, Gonzalez A. Pasteurella multocida septicaemia in a patient on haemodialysis. BMJ Case Rep 2009;2009:10.1136/ bcr.01.2009.1492.

43. Myers EM, Ward SL, Myers JP. Life-threatening respiratory pasteurellosis associated with palliative pet care. Clin Infect Dis 2012;54:e55-7.

44. Writing Panel of Working Group, Lefebvre SL, Golab GC, et al. Guidelines for animal-assisted interventions in health care facilities. Am J Infect Control 2008;36:78-85.

45. Goldstein EJ, Citron DM, Merriam CV, Warren YA, Tyrrell K, Fernandez H. Comparative in vitro activity of ertapenem and 11 other antimicrobial agents against aerobic and anaerobic pathogens isolated from skin and soft tissue animal and human bite wound infections. J Antimicrob Chemother 2001;48:641-51.

46. Goldstein EJ, Citron DM, Merriam CV, Warren YA, Tyrrell KL, Fernandez HT. Comparative in vitro activity of faropenem and 11 other antimicrobial agents against 405 aerobic and anaerobic pathogens isolated from skin and soft tissue infections from animal and human bites. J Antimicrob Chemother 2002;50:411-20.

47. Lion C, Conroy MC, Carpentier AM, Lozniewski A. Antimicrobial susceptibilities of Pasteurella strains isolated from humans. Int J Antimicrob Agents 2006;27:290-93

48. Lion C, Lozniewski A, Rosner V, Weber M. Lung abscess due to beta-lactamase-producing Pasteurella multocida. Clin Infect Dis 1999;29:1345-46.

49. Rosenau A, Labigne A, Escande F, Courcoux P, Philippon A. Plasmid-mediated ROB-1 beta-lactamase in Pasteurella multocida from a human specimen. Antimicrob Agents Chemother 1991;35:2419-22.

50. Kehrenberg C, Schulze-Tanzil G, Martel JL, Chaslus-Dancla E, Schwarz S. Antimicrobial resistance in pasteurella and mannheimia: epidemiology and genetic basis. Vet Res 2001;32:323-39. 
51. Goldstein EJ, Citron DM, Merriam CV. Linezolid activity compared to those of selected macrolides and other agents against aerobic and anaerobic pathogens isolated from soft tissue bite infections in humans. Antimicrob Agents Chemother 1999;43:1469-74.

52. Osmon DR, Berbari EF, Berendt AR, et al. Executive summary: Diagnosis and management of prosthetic joint infection: Clinical practice guidelines by the Infectious Diseases Society of America. Clin Infect Dis 2013;56:1-10.
53. Abrahamian FM, Goldstein EJ. Microbiology of animal bite wound infections. Clin Microbiol Rev 2011;24:231-46.

54. Leone S, Borre S, Monforte A, et al. Consensus document on controversial issues in the diagnosis and treatment of prosthetic joint infections. Int J Infect Dis 2010;14 Suppl 4:S67-77.

55. Stevens DL, Bisno AL, Chambers HF, et al. Practice guidelines for the diagnosis and management of skin and soft tissue infections: 2014 update by the Infectious Diseases Society of America. Clin Infect Dis 2014;59:147-59. 


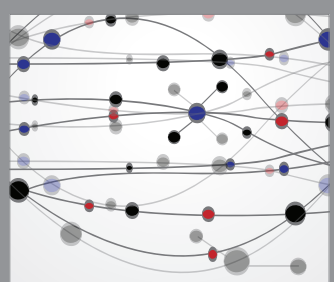

The Scientific World Journal
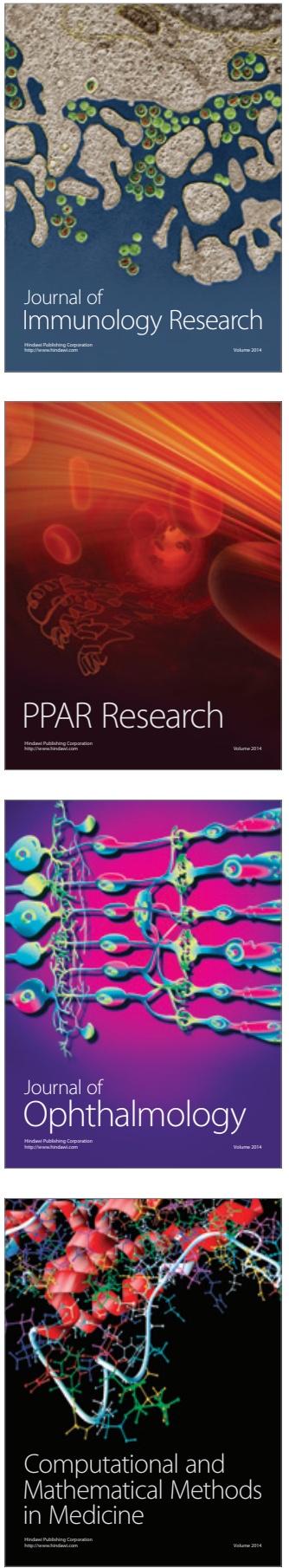

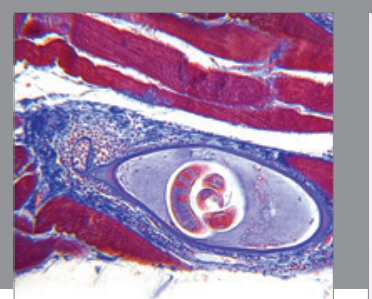

Gastroenterology Research and Practice

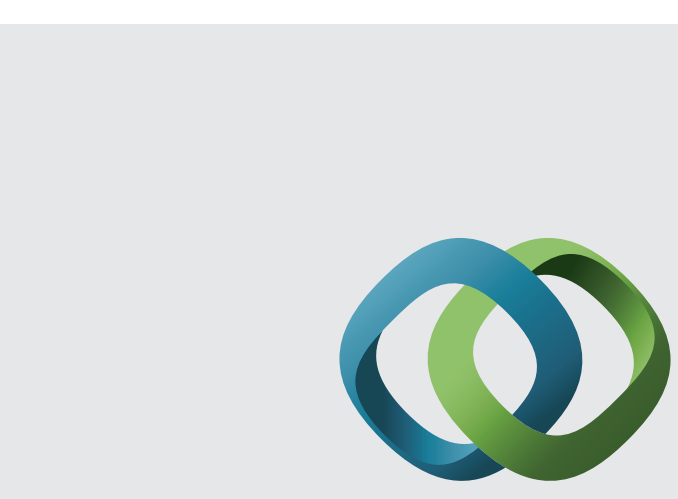

\section{Hindawi}

Submit your manuscripts at

http://www.hindawi.com
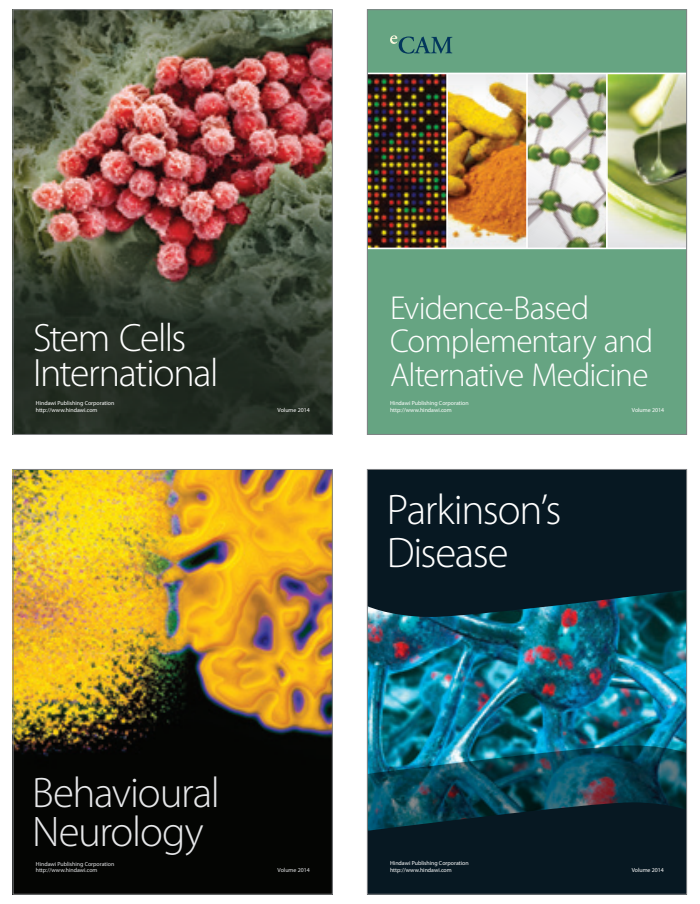
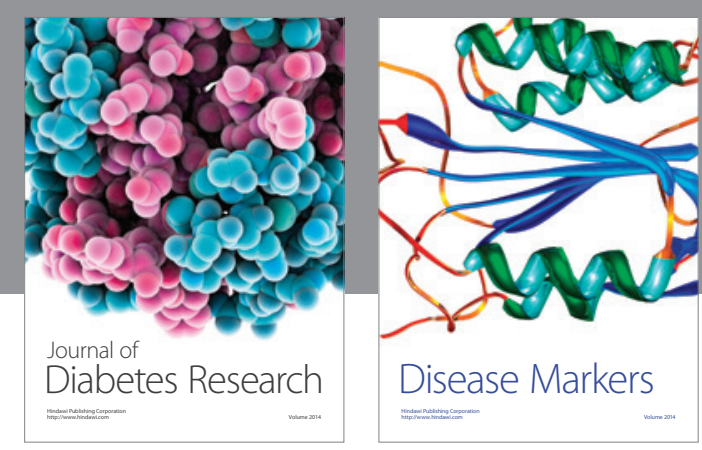

Disease Markers
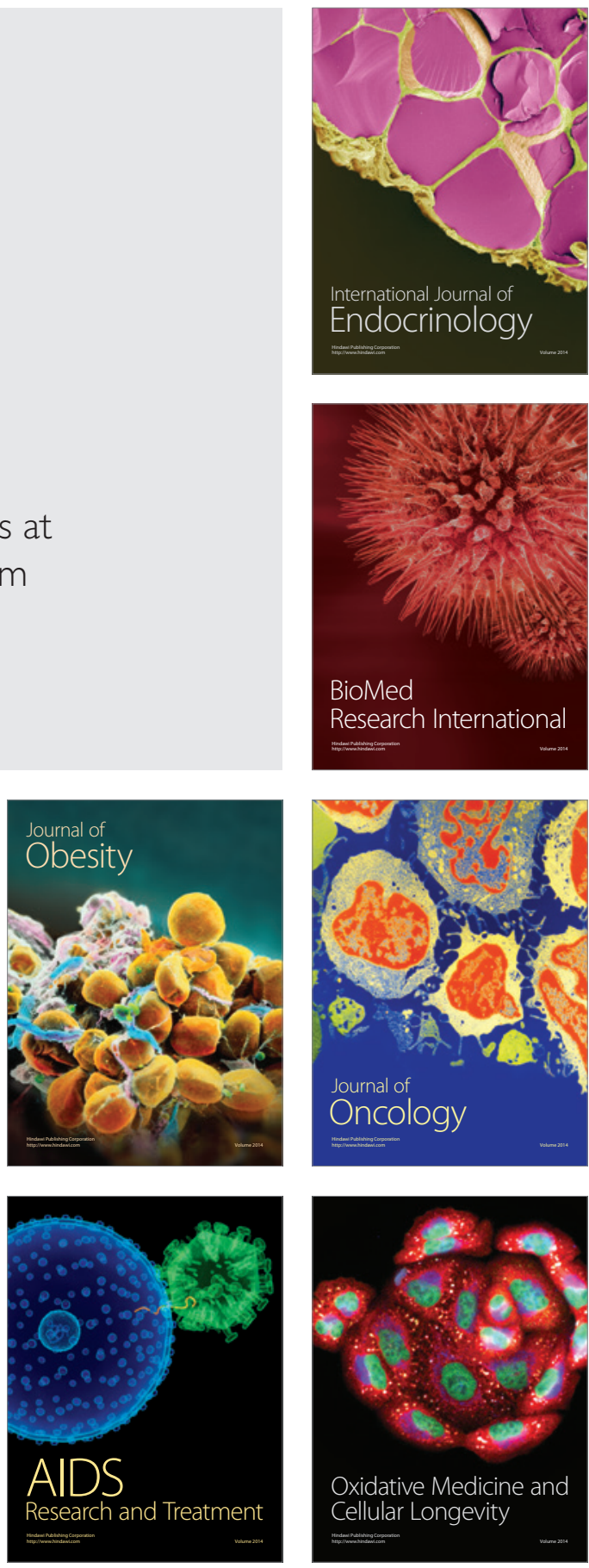